\title{
Article \\ Factors Affecting the Establishment and Growth of Cover Crops Intersown into Maize (Zea mays L.)
}

\author{
Mattie B. Schmitt, Marisol Berti, Dulan Samarappuli and Joel K. Ransom *D
}

Department of Plant Sciences, North Dakota State University, Fargo, ND 58104, USA;

Mattieschmitt41@gmail.com (M.B.S.); Marisol.berti@ndsu.edu (M.B.); Dulan.Samarappuli@ndsu.edu (D.S.)

* Correspondence: joel.ransom@ndsu.edu; Tel.: +1-218-600-6453

Citation: Schmitt, M.B.; Berti, M.; Samarappuli, D.; Ransom, J.K. Factors Affecting the Establishment and Growth of Cover Crops Intersown into Maize (Zea mays L.). Agronomy 2021, 11, 712. https://doi.org/

10.3390/agronomy11040712

Academic Editor: Emanuele Radicetti

Received: 10 March 2021

Accepted: 5 April 2021

Published: 8 April 2021

Publisher's Note: MDPI stays neutral with regard to jurisdictional claims in published maps and institutional affiliations.

Copyright: (C) 2021 by the authors. Licensee MDPI, Basel, Switzerland. This article is an open access article distributed under the terms and conditions of the Creative Commons Attribution (CC BY) license (https:// creativecommons.org/licenses/by/ $4.0 /)$.

\begin{abstract}
In the North Central USA, intersowing cover crops into standing maize (Zea mays L.) is required to establish plants large enough to afford the benefits of a cover since there is limited favorable weather for cover crop growth after maize harvest. The objective of this study was to quantify the impacts of the planting method and time of planting of three cover crop species when grown with or without maize competition on their establishment. Experiments were conducted in three environments during 2018 and 2019. Experiments consisted of a factorial combination of timing of cover crop planting (V7 and R4 growth stage of maize), cover crop species (camelina (Camelina sativa (L.) Crantz), rye (Secale cereale L.), or radish (Raphanus sativus L.), method of sowing (drilled or broadcast), and maize removal. Initial cover crop populations were similar regardless of maize removal or stage of maize when sown, but intersown cover crops produced only $3 \%$ of the fall biomass, compared with treatments with maize-removed when sown at the V7 stage of maize and $14 \%$ when sown at the R4 stage. Limited light intensity (less than $20 \%$ ) under the maize canopy was the main factor affecting interseeded cover crop development. Radish was more sensitive to shading than the other cover crops. Camelina and rye sown at the R4 stage of corn produced similar spring biomass as earlier-sown cover crops. Intersown cover crops had no negative effect on maize grain yield.
\end{abstract}

Keywords: cover crops; camelina; rye; radish; intersowing; photosynthetically active radiation (PAR)

\section{Introduction}

Cover crops have the potential of protecting the soil from erosion, increasing soil organic matter, improving soil aggregate stability and soil water retention, scavenging and releasing nutrients, and stimulating microbial growth and diversity [1-6]. In the upper Midwest of the USA, spring weather conditions prior to primary crop establishment promotes the greatest risk of nitrogen (N) loss in annual cropping systems [7]. According to Randall et al. [8], 69\% of the annual $\mathrm{N}$ loss occurs as runoff in April through June in maize (Zea mays L.)-soybean (Glycine max (L.) Merr.) rotations in the upper Midwest. Winter annual cover crops can be incorporated into maize-soybean rotation to stabilize $\mathrm{N}$ in plant biomass and reduce its loss [9-11]. Although a cover crop that winter kills will not assimilate and retain as much $\mathrm{N}$ in the spring as a cover crop that overwinters, it becomes a valuable option if early spring herbicide applications are undesirable [7]. However, to have a reasonable impact on $\mathrm{N}$ uptake, cover crops need to be well established to have adequate fall and spring growth prior to termination [12,13].

Plants in the family Brassicaceae, henceforth "brassicas" are used as cover crops due to their deep taproot that can grow up to $2 \mathrm{~m}$ deep after four months of growth [14] and rapid root growth of $2 \mathrm{~mm}$ day ${ }^{-1}{ }^{\circ} \mathrm{C}^{-1}$ [15]. Brassica cover crops can take $\mathrm{N}$ up from deep within the soil profile, bringing it closer to the soil surface and within the biomass [6]. Dean and Weil [16] found $\mathrm{N}$ uptake by radish to be greater than or equal to winter rye. Radish $\mathrm{N}$ uptake ranged between 36 and $171 \mathrm{~kg} \mathrm{~N} \mathrm{ha}^{-1}$, and rye uptake ranged between 
42 and $112 \mathrm{~kg} \mathrm{~N} \mathrm{ha}^{-1}$ [16]. In addition, brassicas have a low carbon to nitrogen ratio $(\mathrm{C}: \mathrm{N})$, whereas grasses have a high $\mathrm{C}: \mathrm{N}$ ratio; thus, brassica plant material mineralize faster [17]. Grass cover crops have rapid growth, can tolerate a range of soil conditions, and have fibrous root systems [6]. Although grasses can be effective at remediating shallow compaction layers, brassicas penetrate compacted layers better than grasses [18,19].

There may be negative effects associated with cover crops. Raimbault et al. [20] reported that rye can reduce soil moisture, enough to reduce yield in the following cash crop. A study conducted by Krueger et al. [21] found rye to reduce soil moisture by $13 \%$ when harvested in the spring for grain, compared with no-rye control treatments. However, in the same study, rye that was killed three to four weeks prior to harvest did not significantly reduce soil moisture. To avoid depleting soil moisture, Clark et al. [22] and Liebl et al. [23] suggested terminating rye by early May in the Midwest of the USA. Krueger et al. [21] also reported that rye can utilize available $\mathrm{N}$ and ground cover without reducing available soil water for the following cash crop.

In the North Central region of the USA, it can be challenging to establish cover crops into a maize-soybean rotation because of a narrow planting and establishment window, short growing season, limited photosynthetically active radiation (PAR), and limited soil water availability, and interferences with the following crop [24-27]. The benefits of cover crops on maize and soybean production are highly dependent on environmental conditions [28]. For environments with narrow planting windows and short growing seasons after cash crop harvest, it may be beneficial to sow the cover crops into the standing crop [6]. Intersowing will allow cover crops a longer growing season to establish prior to winter. Planting date, planting method, and competition for solar radiation are all limiting factors to establish interseeded cover crops in maize successfully [29].

Critical planting windows need to be determined in order to know when cover crops can be interseeded most successfully. When cover crops are planted within the critical weed-free period, they can potentially act as weeds and reduce maize yield. The critical weed-free period in maize needed to prevent yield losses greater than $5 \%$ is generally from V1 to V6 stages [30]. According to Curran et al. [31], reduction in maize yield associated with cover crop competition was minimized and cover crop production was maximized when intersown between the V4 and V6 maize growth stages. According to Gallo et al. [32], the percentage of incoming PAR absorbed by the maize canopy increases rapidly from approximately 20 to $90 \%$ between the V5 and V12 maize growth stages. The maize canopy absorbs more than $80 \%$ of incoming PAR from the V12 maize growth stage to the dough stage of grain fill (R4) [32]. Since the incoming PAR absorbed by the maize canopy increases rapidly after V5, the time of planting is critical for the successful establishment of intersown cover crops [32]. It is important that cover crops are planted early enough to establish roots while PAR is reaching the soil surface, but late enough to avoid competing with the primary crop for water, nutrients, and solar radiation [33]. The planting date for cover crops is also important because it influences the amount of biomass they can produce, and biomass is related to the number of nutrients captured $[12,15]$ and the amount of cover provided.

Cover crops can be intersown by broadcasting the seed into the maize crop using aerial equipment or by specifically designed ground equipment. Machinery has been adapted (high-clearance implements) to broadcast or place cover crop seed directly in the inter-row to increase seed-to-soil contact when intersowing cover crops [34]. The improved establishment has been positively associated with methods to increase seedto-soil contact $[31,35,36]$. The planting method can be restricted by planting time. Aerial applications can be conducted anytime throughout the growing season but are typically made in August and September in North Central USA, whereas broadcasting or drilling cover crops with high-clearance implements occur early in the growing season, typically prior to maize emergence until the V7 maize growth stage. The V7 maize growth stage is the latest stage cover crops could be planted with high-clearance implements because any later may result in damage to the maize crop. The success of cover crop establishment when aerially broadcasted into standing maize in August and September was positively 
associated with the occurrence and amount of rainfall within one week of planting [36]. If moisture was not received in a timely manner after broadcasting cover crops, the failure of stand establishment increased [37].

Currently, there is limited information on intersowing cover crops into standing cash crops, and thus, further research is warranted. The objectives of the research conducted were (1) to understand the effects of cover crop planting date and planting method in the North Central USA on the establishment of rye, camelina, and radish when intersown into standing maize and (2) to compare the cover crop growth when grown without the competition of maize.

\section{Materials and Methods}

\subsection{Experimental Sites}

Experiments were conducted at Casselton and Hickson, North Dakota (ND), in 2018, and at Prosper and Hickson, ND, in 2019. The soil types for these three locations are listed in Table 1. For three of the environments, maize followed a previous soybean crop, while at Prosper, maize followed a spring wheat (Triticum aestivum L.) crop. All the sites were managed with conventional tillage prior to maize planting. Daily precipitation and temperature data throughout the two growing seasons were obtained from the North Dakota Agricultural Weather Network (NDAWN) [38] stations at Prosper, ND, and Sabin, $\mathrm{MN}$, which were the stations closest to Casselton and Hickson, ND, respectively.

Table 1. Soil series description of experimental locations at Casselton, Hickson, and Prosper, ND, USA, in 2018 and 2019 [39].

\begin{tabular}{|c|c|c|c|c|}
\hline Location & Series & Texture & Taxonomy & Slope \% \\
\hline Casselton & Kindred-Bearden & Silty clay loam & $\begin{array}{l}\text { Fine-silty, mixed, superactive, } \\
\text { frigid Typic Endoaquolls }\end{array}$ & $0-2$ \\
\hline Hickson & Fargo & Silty clay & $\begin{array}{c}\text { Fine, smectitic, frigid Typic } \\
\text { Epiaquerts }\end{array}$ & $0-2$ \\
\hline Prosper & Kindred-Bearden & Silty clay loam & $\begin{array}{l}\text { Fine-silty, mixed, superactive, } \\
\text { frigid Typic Endoaquolls }\end{array}$ & $0-2$ \\
\hline
\end{tabular}

\subsection{Experimental Design and Management}

The experimental design was a randomized complete block with three replicates. Treatments consisted of four factors in a factorial combination. Cover crops (three levels), cover crop planting methods (two levels), planting date relative to maize growth stage (two levels), and the removal of maize (two levels) were the factors. The three cover crops used were rye, cultivar (cv.) "ND-Dylan"; winter camelina, cv. "Joelle"; and "Daikon" radish. Rye was sown at $45 \mathrm{~kg}$ pure live seed (PLS) ha ${ }^{-1}$, and both camelina and radish were sown at $8 \mathrm{~kg}$ PLS ha ${ }^{-1}$. The two cover crop planting dates were relative to the V7 and R4 maize growth stages, which were determined visually. When planting cover crops, drilling or broadcast methods were used. The final factor was maize removal, i.e., maize was removed or retained at each cover crop planting date. This was carried out to determine the potential growth and development of the cover crops when grown without the competition of the maize crop while allowing for soil moisture and nutrient depletion by the maize crop up until just before planting.

In 2018, maize was planted in $7 \mathrm{~m}$ long plots consisting of four rows, with $76 \mathrm{~cm}$ between rows. Since it was difficult to apply herbicide treatments with these smaller alleys, the maize plot dimensions were changed to $6.1 \mathrm{~m}$ long, with a $1.5 \mathrm{~m}$ alley in 2019 . The maize hybrids were 89-day relative maturities, "DKC 39-27" and "DKC 39-28" in 2018 and 2019 , respectively. For both years, the maize sowing rate was 79,000 live seeds ha ${ }^{-1}$, with rows planted north and south in all environments.

Nitrogen $(\mathrm{N})$ fertilizer was broadcast and incorporated in the spring prior to or at maize planting. Nitrogen fertilizer rates varied based on residue nitrate levels in each environment. In 2018, the $\mathrm{N}$ rate was 188 and $135 \mathrm{~kg} \mathrm{ha}^{-1}$ at Casselton and Hickson, 
respectively. In 2019, the $\mathrm{N}$ rate was 112 and $204 \mathrm{~kg} \mathrm{ha}^{-1}$ for Hickson and Prosper, respectively. Weeds were controlled with glyphosate [ $\mathrm{N}$-(phosphonomethyl) glycine] at the labeled rate prior to cover crop sowing at the V7 stage. The maize hybrids used were glyphosate resistant. After planting cover crops, plots were hand weeded as needed for the remainder of the season.

Cover crops were sown between the maize rows by using a v-hoe with two blades to make furrows and by surface broadcasting by hand. These methods were used to simulate planting with a high-clearance drill and an aerial application, respectively. The furrows were made parallel to the maize rows, $15 \mathrm{~cm}$ apart, at various depths in relation to the seed size of the cover crop. Although planting depth could not be precisely fixed with this planting method, efforts were made to sow shallower for the small-seeded cover crops, and deeper for the larger-seeded cover crops. Radish and rye were planted roughly at $13 \mathrm{~mm}$ deep, and camelina was planted roughly $6 \mathrm{~mm}$ deep. There were two rows of cover crops sown in between three maize interrows, making six cover crop rows per plot. These planting methods were used at both the V7 and R4 growth stages and for the treatments in which the maize was removed. In 2018, in the maize-removed plots, the above-ground maize material was removed by hand at both the V7 and R4 growth stages of maize. Maize that was removed at the V7 maize growth stage in 2018 continued to grow back throughout the season, and therefore, in 2019, the herbicide clethodim [(E)-2-[1-[[(3-chloro-2-propenyl) oxy]imino] propyl]- 5-[2-(ethylthio) propyl]-3-hydroxy-2-cyclohexen1-one] was used at $136 \mathrm{~g} \mathrm{ha}^{-1}$ active ingredient to remove the maize at the V7 maize growth stage.

\subsection{Evaluations}

Cover crop growth and development were evaluated throughout the growing season by measuring green canopy cover, plant density, above-ground biomass, and biomass $\mathrm{N}$ content from within the second and third maize rows of the plot. Green canopy cover was measured using Canopeo, a smartphone application developed by the Dept. of Plant and Soil Sciences, Oklahoma State University, USA (www.canopeoapp.com, accessed on 5 April 2021)). It is able to measure the fractional green canopy cover via an image, through the Canopeo application and estimate the green canopy coverage percentage [40]. Pictures of the cover crops were taken $60 \mathrm{~cm}$ above the ground and were used by the application to calculate the percent canopy cover of the soil. The ground cover was measured weekly, beginning two weeks after cover crop establishment until maize harvest, and again in the spring toward the end of April until cover crop termination.

After the cover crops were planted, measurements of photosynthetically active radiation (PAR) were taken every two weeks, between 1000 and $1400 \mathrm{~h}$ Central Daylight Time (CDT) until maize harvest. Measurements were taken by placing the AccuPAR LP-80 Ceptometer (Decagon Devices, Pullman, WA, USA) parallel to the maize rows, under the maize canopy about $15 \mathrm{~cm}$ above the soil while the attached incident light sensor was above the maize canopy, in uninterrupted sunlight; both sensors collected three measurements per plot. This method of measurement makes it possible to determine the percentage of available light that was accessible to the intersown cover crops.

Cover crop stand counts were taken at various times throughout the growing season. At both the V7 and R4 planting dates, there was a count conducted one week after the first plants had emerged. There was a complete stand count conducted on all the plots just prior to maize harvest, then again in the spring of 2019 prior to termination of the 2018 cover crops. The counts were conducted in one of the center inter-rows of the plot and consisted of $1 \mathrm{~m}$ length by the entire distance between the two maize rows.

Cover crop biomass was collected in the fall prior to maize harvest, and again before termination in the following spring (excluding radish since it did not survive the winter). Biomass samples were collected by cutting the plants at the soil surface from $1 \mathrm{~m}$ in length between two maize rows. All samples were placed into paper bags and dried until the weight remained constant. After determining biomass dry weights, a Cyclone Sample Mill (UDY Corporation, Fort Collins, CO, USA) was used to finely grind the biomass to 
pass through a $1.0 \mathrm{~mm}$ mesh. These ground samples were subsequently analyzed for $\mathrm{N}$ content using a near-infrared analyzer (NIR-XDS analyzer, Foss, Inc., Hilleroed, Denmark) following the methods described by Abrams et al. [41].

In the spring, prior to cover crop termination, samples were also taken to determine how much moisture the cover crops had removed. The samples were collected by taking a $7.5 \mathrm{~cm}$ deep soil core regularly during the growing season and a $15 \mathrm{~cm}$ deep core in the spring, placing it in a tin can, weighing the wet soil, drying it for $48 \mathrm{~h}$, and then weighing the dry soil. Gravimetric water content as percent water by soil mass was calculated by subtracting the dry soil weight from the wet soil weight and then dividing by dry soil weight and multiplying by 100 .

\subsection{Statistical Analysis}

All data were analyzed using estimation and statistical inference for generalized linear mixed models (Proc GLM) in SAS 9.3 [42]. Replicate and environment (defined as the combination of location-year) were considered random effects, while cover crops, sowing method, sowing timing, and maize removal were considered fixed effects. Homogeneity of variance tests was performed to determine if environments could be combined. If homogeneous, a combined analysis across environments was conducted. Factors and their interactions were considered significant at the $\alpha=0.05$ level. If there were significant interactions, the least significant difference (LSD) method was used to separate means.

\section{Results and Discussion}

Soil moisture levels varied between environments, and although there were dry periods and periods of excess moisture, rainfall, in general, was adequate and timely enough to permit germination and establishment of the cover crops (Figure 1). Rainfall just prior to or shortly after inter-seeding cover crops is important because the maize crop at the inter-seeding dates used in this experiment was well established and could quickly deplete stored soil moisture in the surface layers. Inadequate soil moisture was found to delay germination significantly, reduce the emergence of inter-seeded cover crops, and increase their mortality after establishment when rainfall did not meet the demands of the growing maize crop [43].

\subsection{Cover Crop Plant Density}

Rye and radish established at higher densities when drilled compared with broadcasting at the V7 maize growth stage (Table 2). Camelina, however, established similar populations regardless of planting method. Cover crop establishment was as good or better when sown at the R4 stage compared with the V7 stage. At the R4 maize growth stage, the method of planting did not impact cover crop stand establishment regardless of crop. The role of environmental conditions on initial plant densities can be seen in the differences in the two planting dates in this experiment. The reduced plant density for the early planting could be attributed to a dry period during cover crop emergence in Hickson in 2018 and excessive rainfall in 2019, for both locations (Figure 1). The initial plant density varied by cover crop species and was partly related to the number of seeds sowed (camelina, rye, and radish were sown at 1.2 million, 450,000, and 250,000 seeds ha ${ }^{-1}$, respectively). Camelina had higher plant densities when compared with the other species in line with its relative seeding rate. However, rye, when drilled at the early planting date, had a similar initial plant density to that of camelina. Mohammed et al. [37] reported similar or higher populations of rye in all locations to those found in this experiment when inter-seeded at the R4 stage of maize or later, but lower populations of camelina. In their study, the cover crops seeds were lightly incorporated to improve soil-seed contact, and much higher seeding rates were used [37]. Given the differences in seed size between the species, the environment and planting method can logically play an important role in their establishment because seed size affects the amount of moisture needed for germination, and soil-seed contact affects the amount of moisture available to the seed from the soil, particularly in 
the absence of rainfall. For a crop with a seed size such as rye (or larger), rainfall shortly after sowing can be especially important to its establishment when broadcast [44]. The fact that rye established relatively well when broadcast in this experiment, even when not covered by soil (drilled), supports that good stands may be achieved when following a currently published recommendation that rye and other cover crops with similar seed size can be established by broadcasting them from an airplane in maturing maize [45].

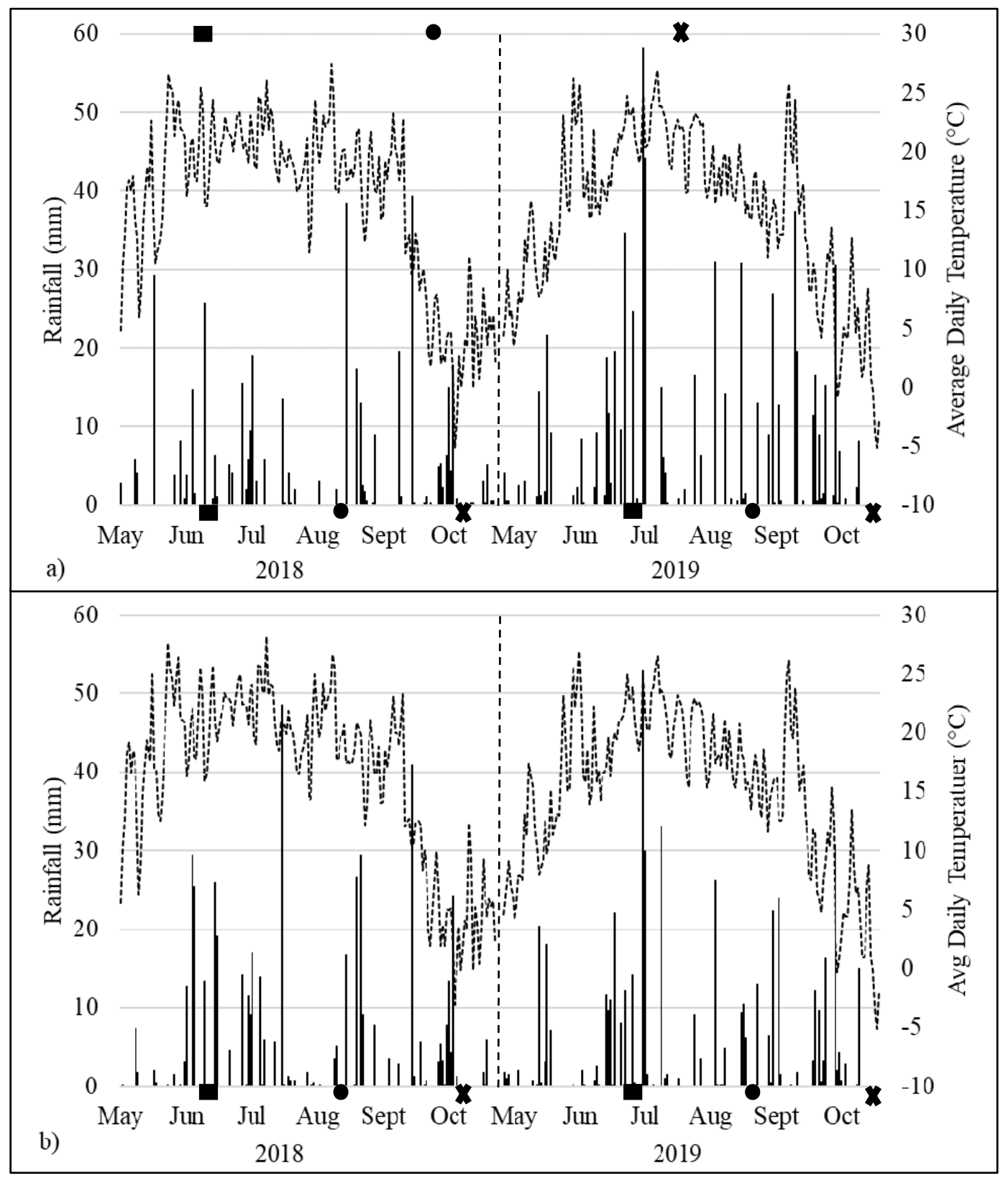

Figure 1. Average daily temperature (dashed line) and daily rainfall (solid bars) at (a) Prosper, ND, and (b) Sabin, MN, weather stations from 1 May to 31 October 2018 and 1 May to 31 October 2019.

Rye and camelina plant density in the fall (just prior to maize harvest) differed between planting dates and planting methods (Table 2). However, radish had similar plant densities for both planting dates within each planting method. Cover crop plant densities declined markedly between the initial count and that taken at the time of biomass harvest in the fall. This might be partly explained by the excess moisture toward the end of the season in 2019. However, the largest reduction in plant population by the time of counting in the fall 
occurred with the cover crops that were planted at the V7 maize growth stage. This was particularly the case for radish and camelina. Mohammed et al. [37] found higher rates of plant establishment of rye and camelina as planting was delayed. They did not see the large decline in populations we observed as the season progressed probably because their earliest planting date was at the R4 stage. The lack of light intensity when the maize crop's canopy is fully developed exerts significant stress that, when combined with other stresses such as excess or limited moisture, has a pronounced effect on plant mortality. Camelina had greater mortality than the other species, with rye the least. There was much less mortality of the established cover crops when planted at the R4 maize growth stage. At this stage, the maize canopy starts to open up and permit more light to reach the developing cover crops; hence, the later planted seedlings experienced less shade stress.

Table 2. Cover crop plant establishment when sown at two different maize growth stages (V7 and R4) and two different planting methods, averaged across two maize-removal treatments and four environments in 2018 and 2019.

\begin{tabular}{|c|c|c|c|c|c|}
\hline \multirow[b]{3}{*}{ Time of Assessment } & \multirow[b]{3}{*}{ Cover Crop } & \multicolumn{4}{|c|}{ Cover Crop Plant Density } \\
\hline & & \multicolumn{2}{|c|}{ Broadcast } & \multicolumn{2}{|c|}{ Drilled } \\
\hline & & V7 & R4 & V7 & R4 \\
\hline & & $-\ldots$ & $---\mathrm{pl}$ & $\ldots$ & -- \\
\hline \multirow{3}{*}{ Initial } & Rye & 43 & 125 & 114 & 137 \\
\hline & Camelina & 199 & 264 & 198 & 291 \\
\hline & Radish & 24 & 57 & 63 & 78 \\
\hline \multirow{5}{*}{ Fall } & $\mathrm{LSD}_{1}=37 ; \mathrm{L}$ & 106; L & & & \\
\hline & Rye & 26 & 95 & 51 & 90 \\
\hline & Camelina & 43 & 198 & 38 & 219 \\
\hline & Radish & 8 & 39 & 18 & 55 \\
\hline & $\mathrm{LSD}_{1}=22 ; \mathrm{L}$ & 65; LS & & & \\
\hline
\end{tabular}

Plant densities at biomass harvest in the fall were impacted by both planting method and planting date. The early planted rye had lower plant densities at maize harvest when broadcasted, compared with drilling, largely due to its better initial establishment when drilled, compared with being broadcast.

Camelina densities were lowest when planted early for both planting methods. Rye had similar plant densities for both planting dates when drilled, whereas the early planted treatments had lower plant densities when broadcasted.

The interaction between cover crops species and maize removal on plant density was significantly different at $p \leq 0.05$. Camelina had different initial densities when comparing intersown and maize-removed treatments, with higher density when intersown (Table 3). Camelina that was both intersown and grown without maize had higher plant densities, compared with rye and radish. Again, this can be attributed to camelina having a higher number of seeds planted when compared with rye and radish.

\subsection{Fall Cover Crop Biomass Yield}

There was a significant interaction between the removal of maize plants at planting and planting date, planting method and planting date, and the removal of maize plants at planting and planting method for fall biomass at $p \leq 0.05$ (ANOVA table not shown). 
Table 3. Mean initial cover crop density for two maize-removal treatments, averaged across four environments at Casselton, Hickson, and Prosper, ND, USA, in 2018 and 2019.

\begin{tabular}{ccc}
\hline & \multicolumn{2}{c}{ Initial Plant Density } \\
\cline { 2 - 3 } Cover Crop & Intersown & Maize-Removed at Time of Planting \\
\hline & 109 & 100 \\
Rye & 259 & 217 \\
Camelina & 61 & 50 \\
Radish & $\mathrm{LS}_{1}(0.05)$ 92; $\mathrm{LSD}_{2} 18$ & \\
\hline
\end{tabular}

Least significant differences $\left(\mathrm{LSD}_{1}\right)$ to compare between means of different cover crop species for the same intersown or maize-removed treatments. $\mathrm{LSD}_{2}$ to compare between means of interseeded and maize- removed treatments for same cover crop species.

Cover crops that were planted at the V7 maize growth stage without maize produced nearly 40 times more biomass in the fall, compared with those that were intersown (Table 4). Without maize competition, at the V7 stage, early planted cover crops produced about five times the biomass, compared with when they were planted later at the R4 stage. Additionally, the planting date did not impact intersown fall cover crop biomass. This was largely due to the limited growth of the cover crops when grown under a maize canopy. A substantial amount of the measured biomass accumulated after the maturity of maize as the canopy opened and greater light reach the cover crops. Fall cover crop biomass was less than $100 \mathrm{~kg} \mathrm{ha}^{-1}$ when intersown. There are many proposed benefits associated with living covers, but the amount of growth and biomass needed to bring about these benefits have not been clearly established. For weed suppression and $\mathrm{N}$ retention services, however, optimum biomass levels occur at around $3000 \mathrm{~kg} \mathrm{ha}^{-1}$ or above, with little benefit occurring with biomass levels below $1000 \mathrm{~kg} \mathrm{ha}^{-1}$ [42].

Table 4. Effect of sowing date and maize removal at the time of sowing on cover crop biomass and total nitrogen content in this biomass averaged over locations and cover crop species.

\begin{tabular}{|c|c|c|c|}
\hline & & \multicolumn{2}{|c|}{ Maize Removal Treatment } \\
\hline & & Inter-Seeded & Maize Removed \\
\hline & Sowing date & - . . . . . . - & 1 - . . . . . . . . . \\
\hline \multirow{2}{*}{ Biomass } & Maize at V7 stage & 76 & 3005 \\
\hline & Maize at R4 stage & 85 & 603 \\
\hline \multirow{4}{*}{$\mathrm{N}$ content } & $\mathrm{LSD}_{1}(0.05) 1302$ & \multicolumn{2}{|c|}{$\mathrm{LSD}_{2}(0.05) 900$} \\
\hline & Maize at V7 stage & 2.5 & 67.3 \\
\hline & Maize at $\mathrm{R} 4$ stage & 3.3 & 13.5 \\
\hline & $\mathrm{LSD}_{3}(0.05) 28.9$ & \multicolumn{2}{|c|}{$\mathrm{LSD}_{4}(0.05) 24.0$} \\
\hline
\end{tabular}

Least significant difference $\left(\mathrm{LSD}_{1}\right.$ and $\left.\mathrm{LSD}_{3}\right)$ to compare between means of intersown and maize-removed treatments for the same sowing date. $\mathrm{LSD}_{2}$ and $\mathrm{LSD}_{4}$ to compare means of the same intersown or maize-removed treatments between different sowing dates.

The amount of cover crop $\mathrm{N}$ uptake measured in the fall was significantly different at $p \leq 0.05$ when comparing planting methods and the interaction between planting date and removal of maize plants at the time of planting. Cover crops when planted early in the season without competition from maize took up higher amounts of $\mathrm{N}$ when compared with later sown cover crops (Table 4). Intersown cover crops, however, did not show a difference for different planting dates and took up limited amounts $\mathrm{N}\left(\sim 3 \mathrm{~kg}\right.$ per ha $\left.{ }^{-1}\right)$ by the end of the growing season. The low $\mathrm{N}$ update is associated with the minimal biomass produced, which was far below the optimal biomass level needed for $\mathrm{N}$ services [13].

The planting method and planting date significantly impacted fall cover crop biomass at $p \leq 0.05$. When considering both planting methods, cover crops planted at the V7 maize growth stage produced greater biomass, compared with that of the R4 stage (Table 5). Furthermore, drilled cover crops produced a higher amount of fall biomass at the V7 
planting date, compared with biomass resulting from broadcasted cover crops. The large difference in biomass between the planting dates can be attributed to the accumulations when the maize crop was removed. Cover crops when planted early that were drilled produced more biomass than when broadcast, particularly when maize was removed. Although the data are not shown, plant $\mathrm{N}$ uptake was similarly impacted by planting method and timing because $\mathrm{N}$ update was closely related to biomass accumulation.

Table 5. Mean fall cover crop biomass yield for two sowing methods, sown at two different maize growth stages averaged across three cover crops, maize removal treatments, and four environments in 2018 and 2019.

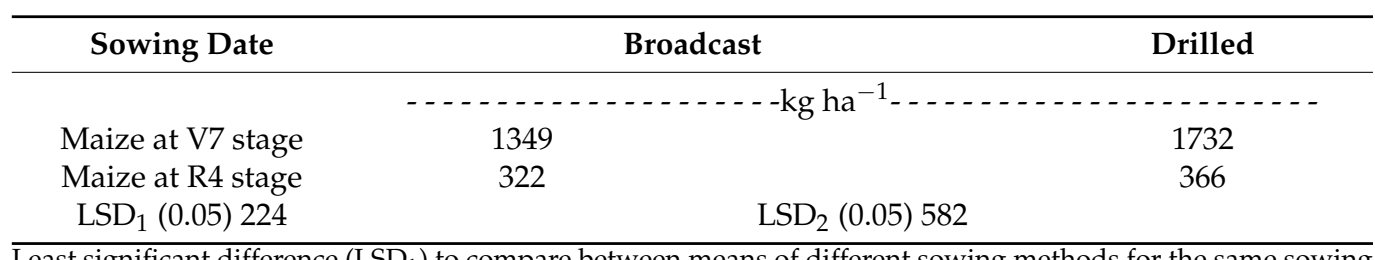

Least significant difference $\left(\mathrm{LSD}_{1}\right)$ to compare between means of different sowing methods for the same sowing date. $\mathrm{LSD}_{2}$ to compare between means of different sowing dates for the same sowing method.

\subsection{Light Intensity and Cover Crop Ground Coverage}

There was a large decline in the amount of photosynthetic active radiation (PAR) reaching the cover crops by the third week after cover crop planting (Figure 2). When planted at the V7 stage, maximum shading by the maize plants occurred approximately five weeks after cover crops were planted.

Maize reached the R4 growth stage about eight weeks after the first planting date of the cover crops. Available PAR at the soil surface and for cover crops planted at the R4 maize stage began to increase as the lower maize leaves started to senesce. However, there was still less than $20 \%$ of the potential PAR available.

Green cover (GC) from cover crops planted at the V7 stage declined as PAR levels declined through to the full canopy of the maize, illustrating the significant stress imposed on the development of plants by the low light intensity within the maize canopy (Figure 2). There was an exception to this trend in Prosper 2019, where GC by the cover crops continually increased after planting. This could be attributed to the delay in full canopy development by the maize crop due to leaf damage by hail. With the extra light during the early development of the cover crops, they were able to continuously grow. Although not specifically shown, much of the observed green cover was associated with the radish treatment. Under a full canopy, radish did very poorly with many plants dying, but with the extra light, radish developed much more rapidly relative to the other cover crops. Gradual increases in GC occurred as the maize canopy opened as it reached maturity, but even then the cover crops only produced roughly $5 \%$ ground cover. The exception to this was in Prosper, where it reached roughly 25\% (Figure 2), with most of that cover being from radish (data not shown).

\subsection{Maize Grain Yield}

Maize yield was lower in Hickson 2018 and Prosper 2019 (Table 6). Both Hickson 2018 and Prosper 2019 locations began the maize growing season with environmental stress. In 2018, the Hickson location began the season dry and the maize did not receive rain in a timely manner after planting. Hickson only received a total of $29 \mathrm{~mm}$ within a month's span after maize planting (Figure 1). Alternatively, in 2019, Prosper received hail and wind damage at the V7 maize growth stage, around 8 July. The hail damage reduced the amount of photosynthetic radiation uptake, thus negatively impacting yield. Although Hickson 2018 and Prosper 2019 had different environmental stresses, both environments had similar yields (Table 6). 


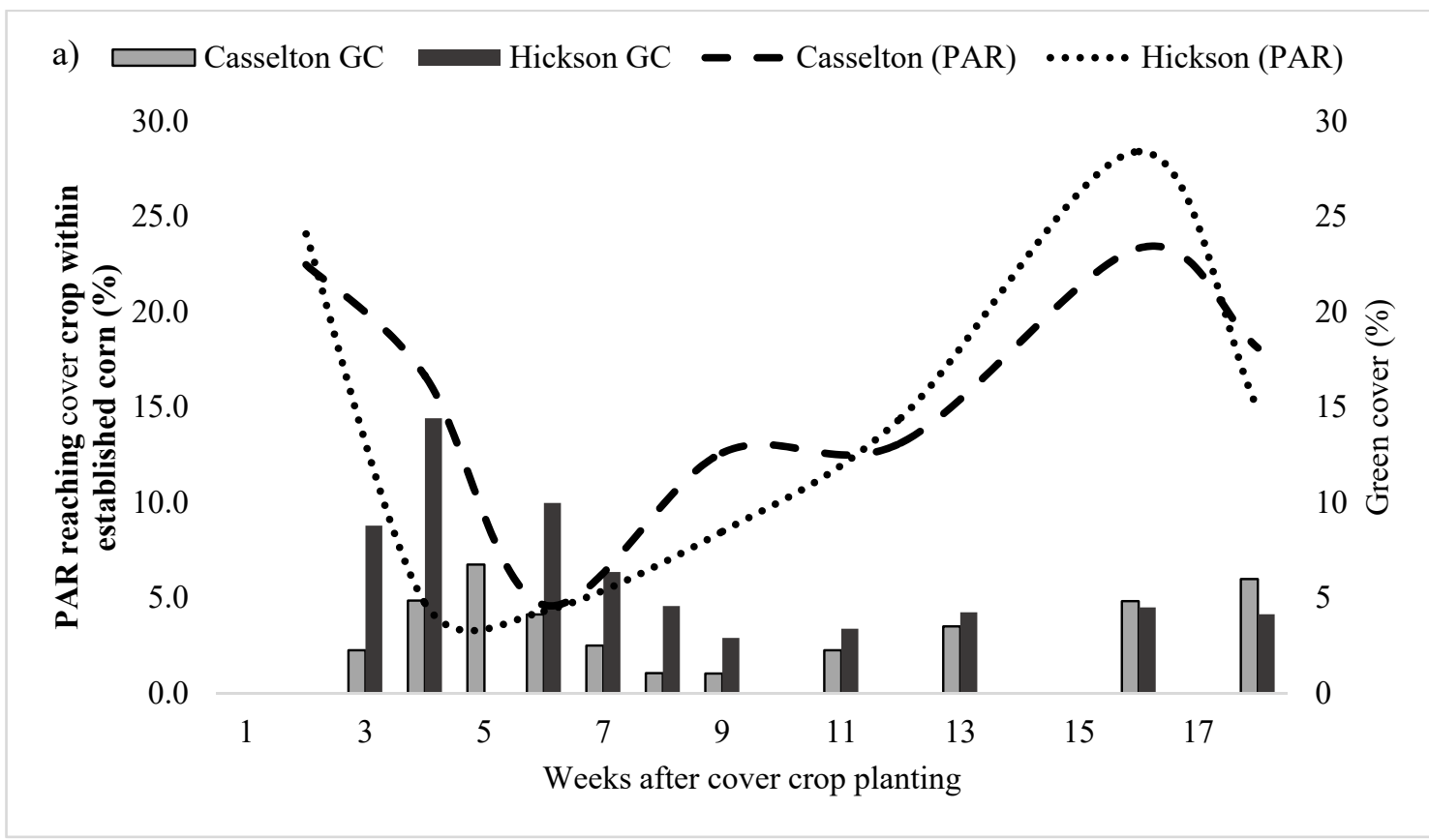

b) Hickson GC

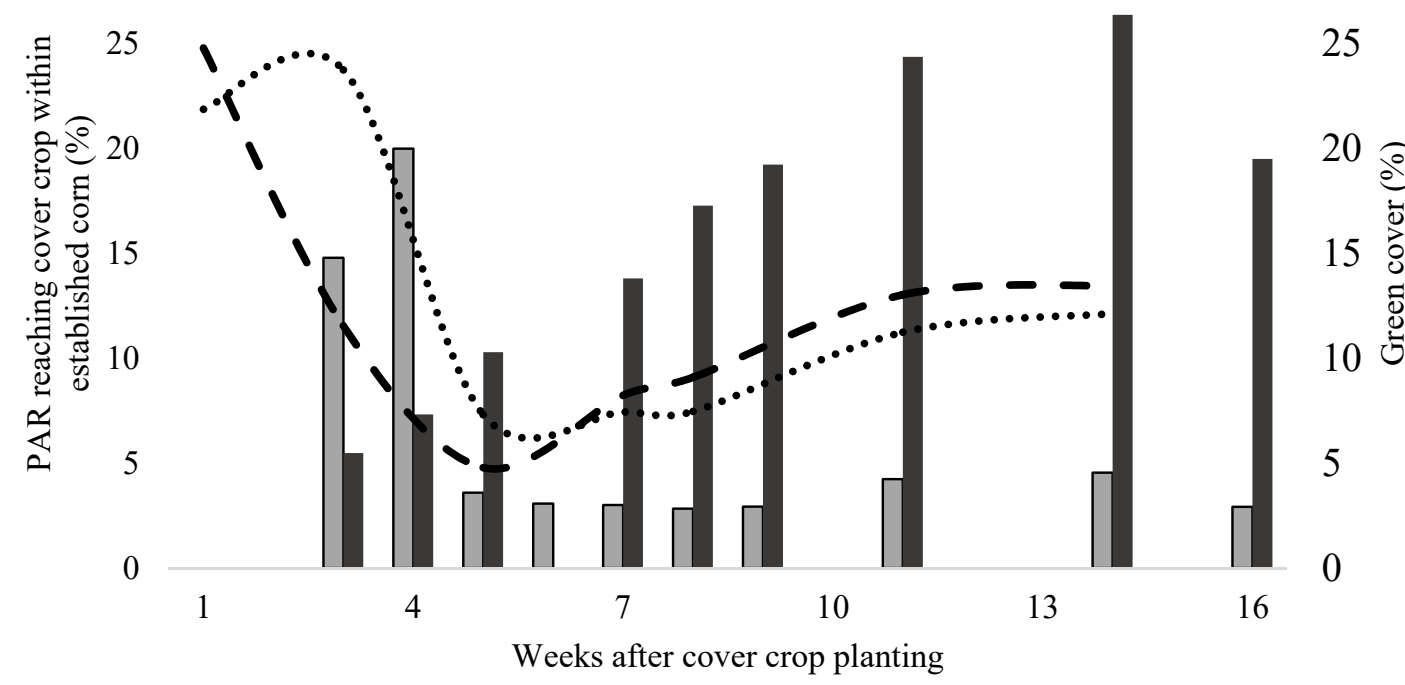

Figure 2. Percent green cover (GC) for cover crops planted at the V7 maize growth stage in relation to photosynthetically active radiation (PAR) reaching the cover crop canopy within the established maize at (a) Casselton and Hickson, ND, in 2018 and (b) Hickson and Prosper, ND, in 2019.

When combined across all environments, there was no effect of cover crop species, cover crop planting date, or planting method on maize yield. Overall, differences in maize yield across environments can be attributed to various environmental weather conditions. The experiments did not include a treatment in which no cover crop was intercropped. This was due to the factorial design used and the fact that previous research with some similar intercropping treatments found that they did not influence maize yield [43]. Berti et al. [30] and Noland et al. [7] report that the V1-V6 maize growth stages are the critical "weed-free" period when maize is sensitive to competition. Cover crops were planted at the V7 stage or 
later were outside this critical period. Moreover, the minimal biomass produced by the early seeded cover crops shows that there was little potential for them to exert significant competition with the maize (Table 4).

Table 6. Mean maize grain yield for three cover crops at four environments averaged across two sowing dates at Casselton, Hickson, and Prosper, ND, USA, in 2018 and 2019.

\begin{tabular}{|c|c|c|c|c|}
\hline & \multicolumn{4}{|c|}{ Environment } \\
\hline & \multicolumn{2}{|c|}{2018} & \multicolumn{2}{|c|}{2019} \\
\hline Cover Crop & Casselton & Hickson & Hickson & Prosper \\
\hline & \multicolumn{4}{|c|}{ 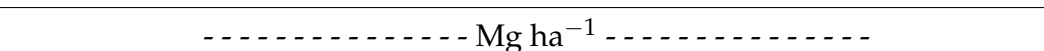 } \\
\hline Rye & 14.5 & 12.9 & 14.3 & 12.0 \\
\hline Camelina & 14.6 & 12.0 & 13.3 & 12.9 \\
\hline Radish & 14.2 & 12.2 & 14.3 & 12.8 \\
\hline $\operatorname{LSD}(0.05)$ & 2.1 & & & \\
\hline
\end{tabular}

\subsection{Spring Cover Crop Growth}

Rye and camelina plant densities were not recorded, and spring biomass prior to soybean planting was used to estimate cover crop survival and regrowth. Radish is not a winter annual; thus, plants did not survive the winter. It was observed that most rye and camelina plants survived the winter, with the exception of those that were established at the V7 stage, in which maize had been removed, and especially for camelina. Berti et al. [30] found earlier that planted camelina loses its winter hardiness if it is exposed to summer heat.

Spring cover crop biomass was impacted by planting date and whether the cover crops were interseeded or grown without maize. There was an interaction between species when compared within planting times and interseeded or maize-removed treatments. Rye produced greater spring biomass, compared with camelina, when planted at the V7 maize growth stage in maize-removed treatments (Table 7). Camelina when planted at the V7 stage had much greater winter mortality than did rye. Early planted camelina that grew beyond the rosette stage prior to winter dormancy did not survive and struggled with the summer heat, which reduced its winter hardiness. Rye tolerated early planting somewhat better than camelina, when intersown (Table 7), but even some of the large rye plants that had been planted at the V7 stage without a maize cover were observed to die during the winter. The amount of spring biomass of cover crops when intersown was just approaching the level at which their leaves were covering the soil surface, reducing soil moisture, with the potential to suppress weeds and take up available nitrogen. Rye performed far better than camelina. At the time of termination, however, the biomass was far less than required to provide optimum ecosystem services desired from cover crops [42] due to the short spring growing season associated with cool spring weather and the recommendation to plant soybeans by 20 May in North Dakota in order to optimize yield.

Table 7. Mean spring cover crop biomass prior to soybean planting for two cover crops sown at two maize growth stages (V7 and R4), and two maize removal treatments averaged across four environments at Casselton, Hickson, and Prosper, ND, USA, in 2019 and 2020.

\begin{tabular}{|c|c|c|c|c|}
\hline \multirow{2}{*}{ Cover Crop } & \multicolumn{2}{|c|}{ Intersown } & \multicolumn{2}{|c|}{ Maize-Removed } \\
\hline & V7 & $\mathbf{R} 4$ & V7 & R4 \\
\hline & $\ldots$ & $-\ldots$ & $\ldots$ & $\ldots$ \\
\hline Rye & 137 & 238 & 1199 & 1173 \\
\hline Camelina & 27 & 73 & 6 & 396 \\
\hline \multicolumn{2}{|c|}{$\mathrm{LSD}_{1}(0.05) 229$} & & \multicolumn{2}{|c|}{$\mathrm{LSD}_{2}(0.05) 689$} \\
\hline
\end{tabular}

Least significant difference (LSD 1 ) to compare between means of cover crop species for the same sowing date and maize-removal method. $\mathrm{LSD}_{2}$ to compare between means of sowing dates for the same cover crop and maize-removal method. 


\section{Conclusions}

Establishing cover crops that will consistently provide effective ecosystem benefits in a maize-based cropping system is challenging due to the intense shading of the maize canopy when it is actively growing and the limited favorable weather for cover crop growth after maize maturity. When planted at the V7 stage, the latest stage considered practical for mechanical incorporation of the cover crops at the time of planting, cover crop mortality rates were high due to low light intensity. Radish was generally more sensitive than rye or camelina to low light intensity. Camelina planted at the V7 growth stage of maize did not overwinter well and should only be recommended as a winter annual cover crop when planted later in the summer. Cover crops tended to establish better when mechanically incorporated than when broadcast, and the small-seeded camelina tended to establish better than radish or rye when broadcast. Nevertheless, the establishment of rye when broadcast was considered to be good enough to be recommended for seasons and locations where soil moisture will be sufficient to enable germination. Sowing winter annual cover crops as maize approaches maturity ( $\mathrm{R} 4$ growth stage) generally produced as much biomass in the fall as when planted earlier and tended to overwinter better. The amount of biomass and ecosystem services provided by winter annual cover crops that do establish and overwinter will depend on when they are terminated in the spring. Winter annual cover crops may only marginally provide $\mathrm{N}$ cycling and weed suppression benefits if soybeans are the following crop and are planted around the middle of May. Maize yield did not differ regardless of cover crop treatments because their growth was minimal due to the shading of the maize crop after they were planted.

Author Contributions: M.B.S.: Conceptualization, Formal analysis, Investigation, Methodology, Writing-original draft, Writing—review \& editing. M.B.: Formal analysis, Funding acquisition, Investigation, Project administration, Resources, Writing—review \& editing. D.S.: Writing-review \& editing. J.K.R.: Conceptualization, Investigation, Supervision, Writing-review \& editing. All authors have read and agreed to the published version of the manuscript.

Funding: This project was funded by USDA-NIFA, Award no. 2016-69004-24784.

Acknowledgments: The authors would like to acknowledge the technical assistance provided by Chad Deplazes and Darin Eisinger.

Conflicts of Interest: The authors declare no conflict of interest.

\section{References}

1. Dabney, S.M.; Delgado, J.A.; Reeves, D.W. Using winter cover crops to improve soil and water quality. Commun. Soil Sci. Plant Anal. 2001, 32, 1221-1250. [CrossRef]

2. Kaspar, T.C.; Radke, J.K.; Laflen, J.M. Small grain cover crops and wheel traffic effects on infiltration, runoff, and erosion. J. Soil Water Cons. 2001, 56, 160-164.

3. De Baets, S.; Poesen, J.; Meersmans, J.; Serlet, L. Cover crops and their erosion-reducing effects during concentrated flow erosion. Catena 2011, 85, 237-244. [CrossRef]

4. Chen, G.; Weil, R.R.; Hill, R. Effects of compaction and cover crops on soil least limiting water range and air permeability. Soil Till. Res. 2014, 136, 61-69. [CrossRef]

5. Lounsbury, N.P.; Weil, R.R. No-till seeded spinach after winterkilled cover crops in an organic production system. Renew. Agric. Food Syst. 2015, 30, 473-485. [CrossRef]

6. Wick, A.; Berti, M.; Lawley, L.; Liebig, M. Integration of annual and perennial cover crops for improving soil health. In Soil Health and Intensification of Agroecosystems; Al-Kaisi, M.M., Lowery, B., Eds.; Academic Press: Oxford, UK, 2017; pp. 127-150.

7. Noland, R.L.; Wells, M.S.; Sheaffer, C.C.; Baker, J.M.; Martinson, K.L.; Coulter, J.A. Establishment and function of cover crops interseeded into maize. Crop Sci. 2018, 58, 863-873. [CrossRef]

8. Randall, G.W.; Vetsch, J.A.; Huffman, J.R. Nitrate losses in subsurface drainage from a maize-soybean rotation as affected by time of nitrogen application and use of nitrapyrin. J. Environ. Qual. 2003, 32, 1764-1772. [CrossRef] [PubMed]

9. Feyereisen, G.W.; Wilson, B.N.; Sands, G.R.; Strock, J.S.; Porter, P.M. Potential for a rye cover crop to reduce nitrate loss in southwestern Minnesota. Agron. J. 2006, 98, 1416-1426. [CrossRef]

10. Qi, Z.; Helmers, M.J. Soil water dynamics under winter rye cover crop in central Iowa. Vadose Zone J. 2010, 9, 53-60. [CrossRef]

11. Blanco-Canqui, H.; Shaver, T.M.; Lindquist, J.L.; Shapiro, C.A.; Elmore, R.W.; Francis, C.A.; Hergert, G.W. Cover crops and ecosystem services: Insights from studies in temperate soils. Agron. J. 2015, 107, 2449-2474. [CrossRef] 
12. Komatsuzaki, M.; Wagger, M.G. Nitrogen recovery by cover crops in relation to time of planting and growth termination. J. Soil Water Conserv. 2015, 70, 385-398. [CrossRef]

13. Finney, D.M.; White, C.M.; Kaye, J.P. Biomass production and carbon/nitrogen ratio influence ecosystem services from cover crop mixtures. Agron. J. 2016, 108, 39-52. [CrossRef]

14. Thorup-Kristensen, K.; Cortasa, M.; Loges, R. Winter wheat roots grow twice as deep as spring wheat roots, is this important for N uptake and N leaching losses? Plant Soil 2009, 322, 101-114. [CrossRef]

15. Thorup-Kristensen, K. Are differences in root growth of nitrogen catch crops important for their ability to reduce soil nitrate-N content, and how can this be measured? Plant Soil 2001, 230, 185-195. [CrossRef]

16. Dean, J.E.; Weil, R.R. Brassica cover crops for N retention in the Mid-Atlantic coastal plain. J. Environ. Qual. 2009, 38, 520-528. [CrossRef]

17. SARE (Sustainable Agriculture Research and Education). Managing Cover Crops Profitably, 3rd ed.; SARE: College Park, MD, USA, 2012

18. Materechera, S.A.; Alston, A.M.; Kirby, J.M.; Dexter, A.R. Influence of root diameter on the penetration of seminal roots into a compacted subsoil. Plant Soil 1992, 144, 297-303. [CrossRef]

19. Chen, G.; Weil, R.R. Penetration of cover crop roots through compacted soils. Plant Soil 2010, 331, 31-43. [CrossRef]

20. Raimbault, B.A.; Vyn, T.J.; Tollenaar, M. Maize response to rye cover crop, tillage methods, and planter options. Agron. J. 1991, 82, 1088-1093. [CrossRef]

21. Krueger, E.S.; Ochsner, T.E.; Porter, P.M.; Baker, J.M. Winter rye cover crop management influences on soil water, soil nitrate, and maize development. Agron. J. 2011, 103, 316-323. [CrossRef]

22. Clark, A.J.; Decker, A.M.; Meisinger, J.J.; McIntosh, M.S. Kill date of vetch, rye, and a vetch rye mixture: II. Soil moisture and maize yield. Agron. J. 1997, 89, 434-441. [CrossRef]

23. Liebl, R.; Simmons, F.W.; Wax, L.M.; Stoller, E.W. Effect of rye (Secale cereal) mulch on weed control and soil moisture in soybean (Glycine max). Weed Technol. 1992, 6, 838-846. [CrossRef]

24. Bich, A.D.; Reese, C.L.; Kennedy, A.C.; Clay, D.E.; Clay, S.A. Maize yield is not reduced by mid-season establishment of cover crops in northern Great Plains environments. Crop Manag. 2014, 13. [CrossRef]

25. Belfry, K.D.; Van Eerd, L.L. Establishment and impact of cover crops intersown into maize. Crop Sci. 2016, 56, 1245-1256. [CrossRef]

26. Singer, J.W. Maize belt assessment of cover crop management and preferences. Agron. J. 2008, 100, 1670-1672. [CrossRef]

27. SARE-CTIC. Cover Crop Survey: 2015-2016 Annual Report. Conservation Technology Information Center, Sustainable Agriculture Research and Education, American Seed Trade Association. 2016. Available online: http://www.sare.org/Learning-Center/TopicRooms /Cover-Crops /Cover-Crop-Surveys (accessed on 16 January 2021).

28. Unger, P.W.; Vigil, M.F. Cover crop effects on soil water relationships. J. Soil Water Conserv. 1998, 53, $200-207$.

29. Humphreys, M.T.; Freeman, K.W.; Mullen, R.W.; Keahey, D.A.; Teal, R.K.; Raun, W.R. Canopy reduction and legume interseeding in irrigated continuous maize. J. Plant Nutr. 2003, 26, 1335-1343. [CrossRef]

30. Berti, M.; Samarappuli, D.; Johnson, B.L.; Gesch, R.W. Integrating winter camelina into maize and soybean cropping systems. Ind. Crops Products. 2017, 107, 595-601. [CrossRef]

31. Curran, W.S.; Hoover, R.J.; Roth, G.W.; Wallace, J.M.; Dempsey, M.A.; Mirsky, S.B.; Ackroyd, V.J.; Ryan, M.R.; Pelzer, C.J. Evaluation of cover crops drill-interseeded into corn across the Mid-Atlantic. Crops Soils 2018, 51, 18-25. [CrossRef]

32. Gallo, K.P.; Daughtry, C.S.T.; Bauer, M.E. Spectral estimation of absorbed photosynthetically active radiation in maize canopies. Remote Sens. Environ. 1985, 17, 221-232. [CrossRef]

33. Abdin, O.A.; Coulman, B.E.; Cloutier, D.C.; Faris, M.A.; Smith, D.L. Establishment, development, and yield of forage legumes and grasses as cover crops in grain maize in eastern Canada. J. Agron. 2018, 110, 2211-2221.

34. Roth, G.W.; Curran, W.S.; Dillon, C.; Houser, C.; Harkcom, W.S. Cover Crop Interseeder and Applicator; Pennsylvania State Univ.: University Park, PA, USA, 2015.

35. Boyd, N.S.; Van Acker, R.C. The effects of depth and fluctuating soil moisture on the emergence of eight annual and six perennial plant species. Weed Sci. 2003, 51, 725-730. [CrossRef]

36. Wilson, M.L.; Baker, J.M.; Allan, D.L. Factors affecting successful establishment of aerially seeded winter rye. J. Environ. Qual. 2013, 33, 1010. [CrossRef]

37. Mohammed, Y.A.; Matthees, H.L.; Gesch, R.W.; Patel, S.; Forcella, F.; Aasand, K.; Steffl, N.; Johnson, B.L.; Wells, M.S.; Lenssen, A.W. Establishing winter annual cover crops by interseeding into maize and soybean. Agron. J. 2020, 112, 719-732. [CrossRef]

38. NDAWN. North Dakota Agricultural Weather Network; North Dakota State Univ.: Fargo, ND, USA, 2020; Available online: http: / / ndawn.ndsu.nodak.edu (accessed on 16 January 2021).

39. Web Soil Survey. Natural Resources Conservation Service, United States Department of Agriculture. 2019. Available online: http:/ / websoilsurvey.nrcs.usda.gov / (accessed on 16 January 2021).

40. Patrignani, A.; Ochsner, T.E. Canopeo: A powerful new tool for measuring fractional green canopy cover. Agron. J. 2015, 107, 2312-2320. [CrossRef]

41. Abrams, S.M.; Shenk, J.; Westerhaus, F.E. Determination of forage quality by near infrared reflectance spectroscopy: Efficacy of broad-based calibration equations. J. Dairy Sci. 1987, 70, 806-813. [CrossRef]

42. SAS Institute. SAS User's Guide, 2020: Statistics; SAS Institute: Cary, NC, USA, 2020. 
43. Geiszler, M.M. Interseeding Cereal Rye and Winter Camelina into Maize in North Dakota. Master's Thesis, North Dakota State University, Fargo, ND, USA, 2018. Available online: https:/ /hdl.handle.net/10365/29214 (accessed on 16 January 2021).

44. Fisher, K.A.; Momen, B.; Kratochvil, R.J. Is broadcasting seed an effective winter cover crop planting method? Agron. J. 2011, 103, 472-478. [CrossRef]

45. Midwest Cover Crops Council. Midwest Cover Crops Field Guide; Publ. ID-433; Purdue Univ. Ext.: West Lafayette, IN, USA, 2012. 